\title{
The Effect of Whey Protein Supplementation on the Temporal Recovery of Muscle Function Following Resistance Training: A Systematic Review and Meta-Analysis
}

\author{
Robert W. Davies 1,2,* (D), Brian P. Carson 1,2 (iD) and Philip M. Jakeman 1,2 (iD) \\ 1 Human Science Research Unit, Centre for Interventions in Infection, Inflammation \& Immunity (4i), \\ University of Limerick, Limerick V94 T9PX, Ireland; brian.carson@ul.ie (B.P.C.); phil.jakeman@ul.ie (P.M.J.) \\ 2 Food, Health Ireland, Physical Education and Sport Sciences Department, University of Limerick, \\ Limerick V94 T9PX, Ireland \\ * Correspondence: robert.davies@ul.ie; Tel.: +353-61-374-779
}

Received: 28 December 2017; Accepted: 13 February 2018; Published: 16 February 2018

\begin{abstract}
Whey protein (WP) is a widely consumed nutritional supplement, known to enhance strength and muscle mass during resistance training (RT) regimens. Muscle protein anabolism is acutely elevated following RT, which is further enhanced by WP. As a result, there is reason to suggest that WP supplementation may be an effective nutritional strategy for restoring the acute loss of contractile function that occurs following strenuous RT. This systematic review and meta-analysis provides a synthesis of the literature to date, investigating the effect of WP supplementation on the recovery of contractile function in young, healthy adults. Eight studies, containing 13 randomised control trials (RCTs) were included in this review and meta-analysis, from which individual standardised effect sizes (ESs) were calculated, and a temporal overall ES was determined using a random-effects model. Whilst only half of the individual studies reported beneficial effects for WP, the high-quality evidence taken from the 13 RCTs was meta-analysed, yielding overall positive small to medium effects for WP from $<24$ to $96 \mathrm{~h}$ ( $\mathrm{ES}$ range $=0.4$ to 0.7 ), for the temporal restoration of contractile function compared to the control treatment. Whilst the effects for WP were shown to be consistent over time, these results are limited to $13 \mathrm{RCTs}$, principally supporting the requirement for further comprehensive research in this area.
\end{abstract}

Keywords: athletic performance; dietary supplements; exercise; humans; recovery of function; resistance training; skeletal muscle; sports; weight lifting; whey proteins

\section{Introduction}

Resistance training (RT) is used to increase lean mass, strength, and physical function [1]. The ability to sustain high-quality exercise performance during periods of intense training is a key component for optimal and efficient progression. Strenuous RT can evoke damage or deformation to the working muscle, limiting its capacity to produce force-this may persist for hours or days before full recovery, reducing general 'muscle function' [2,3]. During any subsequent training/performance bout a reduction in muscle function will impair quality and intensity, and is, potentially injurious to the athlete. Protein ingestion is thought to enhance peri-training recovery of muscle function, but the extant literature is, to date, equivocal. Whey protein (WP) is a high-quality source of protein, rich in essential amino acids, known to enhance muscle protein synthesis (MPS) post-exercise [4-7] which is demonstrably superior compared to other lower quality protein sources [8]. Because of these properties, WP is purported to accelerate the recovery of muscle function following RT [9-16], though 
the supporting evidence is far from clear. Evaluation of the evidence for the efficacy for WP may be confounded by experimental factors such as RT mode, subjects' training status, outcome measures, and supplementation strategy. The aim of this systematic review and meta-analysis is to examine and synthesise the current evidence from high-quality randomised control trials (RCTs) in the extant literature, to determine the effect of WP on the recovery of muscle function following RT, in young, healthy adults.

\section{Materials and Methods}

This systematic review and meta-analysis was conducted and reported in accordance with the recommendations of the Preferred Reporting Items for Systematic reviews and Meta-analysis (PRISMA) guidelines [17].

\subsection{Eligibility Criteria}

Studies meeting the following criteria were considered for review and meta-analysis: (1) subjects were healthy, human, adults; (2) the study contained at least two treatments, where at least one treatment was a WP and another was a placebo or control treatment; (3) subjects were randomly assigned to each group or treatment; (4) some form of muscle function was measured (defined below); (5) function was assessed following a RT intervention only (defined below); (6) original research published in peer reviewed indexed journals; and (7) written in English.

Muscle function following RT was analysed as the principal outcome measure. Muscle function was operationally defined as (1) peak force or torque produced during an isometric, isokinetic, or isoinertial maximal voluntary contraction (MVC); or (2) the maximum load that could be lifted, repetitions, or work done during a standardised exercise task. RT was operationally defined as an any exercise consisting of repeated muscle actions opposed by an external (exogenous) force.

Studies were excluded from the review and meta-analysis if: (1) the WP supplement was co-ingested with any other ergogenic aid(s) evidenced to enhance muscle function (e.g., caffeine [18], $\beta$-hydrolxy $\beta$-methylbutyric acid [19], branched chain amino acids [20], or anti-inflammatory drugs, supplements or analgesics [21]); (2) insufficient data was reported to conduct statistical analysis and/or to confirm eligibility; (3) any other temporal therapeutic intervention was conducted during the recovery period (e.g., massage, compression, exercise, heat therapy etc.); and/or (4) data had been duplicated or reported elsewhere.

\subsection{Search Strategy and Study Selection}

A computerised literature search was performed (September 2017 to December 2017) using four online databases: Medline (Pubmed), Web of Science, Science Direct, and the Cochrane library. Title/Abstract/Keyword searches were made using Boolean search operators ("whey protein" or "protein supplement") and ("exercise" or "force" or "function" or "recovery" or "resistance exercise" or "strength training" or "torque" or "weight lifting"). A supplementary search of keywords was made, as were reference lists and citations of all identified studies, using Google Scholar.

A total of $n=930$ studies were identified from the databases and other supplementary searches. After adjusting for duplicates $n=399$ studies remained. During screening $n=354$ were removed following title/abstract review, not meeting eligibility criteria (see above). The full text of the remaining $n=45$ studies was examined in detail; $n=37$ were excluded $(n=14$, reporting no measure of acute function; $n=1$, not written in English; $n=1$, absence of statistical data; $n=3$, not RT; $n=11$, no WP intervention or control; $n=5$, WP supplement was co-ingested with other ergogenic supplements; $n=2$, data duplicated or previously reported). In total $n=8$ studies were included for the systematic review and meta-analysis [9-16] (Table 1), meeting the predefined eligibility criteria set by the authors (see above). 
Table 1. Studies included in the systematic review and meta-analysis.

\begin{tabular}{|c|c|c|c|c|c|c|c|c|c|}
\hline Study & Subjects & Design & QA & Exercise & Load & Supplement(s) & Control & Dose and Timing & Function Measure \\
\hline $\begin{array}{c}\text { Buckley et al., } \\
2010[9]\end{array}$ & $\begin{array}{l}\text { Untrained } \\
\text { men }\end{array}$ & $\begin{array}{l}\text { Parallel } \\
\text { Groups }\end{array}$ & + & $\begin{array}{c}\text { Unilateral, } \\
\text { isokinetic, eccentric, } \\
\text { knee extensions }\end{array}$ & $\begin{array}{c}100 \text { MVCs } \\
\text { no rest reported }\end{array}$ & $\begin{array}{c}\text { WP isolate }(n=11) \\
\text { WP hydrolysate }(n=6)\end{array}$ & $\begin{array}{c}\text { Flavoured Water } \\
(n=11) \\
\text { No dietary control }\end{array}$ & $\begin{array}{c}25 \mathrm{~g} 0 \mathrm{~h}, 6 \mathrm{~h}, 22 \mathrm{~h} \\
\text { post-exercise }\end{array}$ & $\begin{array}{l}\text { Peak isometric knee } \\
\text { extensor strength }\end{array}$ \\
\hline $\begin{array}{l}\text { Cooke et al., } \\
2010[10]\end{array}$ & $\begin{array}{l}\text { Untrained } \\
\text { men }\end{array}$ & $\begin{array}{l}\text { Parallel } \\
\text { Groups }\end{array}$ & + & $\begin{array}{l}\text { Unilateral, eccentric } \\
\text { knee extensions, } \\
\text { flexions, leg presses }\end{array}$ & $\begin{array}{c}4 \text { sets } \times 10 \text { reps } \\
120 \% 1 \text { RM } \\
3 \text { min rest each set }\end{array}$ & $\begin{array}{c}\text { WP hydrolysate + } \mathrm{CHO} \\
(9: 1)(n=9)\end{array}$ & $\begin{array}{c}\text { Isocaloric } \mathrm{CHO} \\
(n=8) \\
\text { No dietary control }\end{array}$ & $\begin{array}{l}1.5 \mathrm{~g} / \mathrm{kg} 0.5 \mathrm{~h} \\
\text { post-exercise plus } \\
\sim 30 \mathrm{~g} \text { with meals } \\
\text { each day } \\
\end{array}$ & $\begin{array}{l}\text { Isometric and isokinetic } \\
\text { knee extensor and } \\
\text { flexor strength }\end{array}$ \\
\hline $\begin{array}{l}\text { Farup et al., } \\
2014 \text { [11] }\end{array}$ & $\begin{array}{l}\text { Untrained } \\
\text { men }\end{array}$ & $\begin{array}{l}\text { Parallel } \\
\text { Groups }\end{array}$ & + & $\begin{array}{c}\text { Unilateral, } \\
\text { isokinetic, eccentric } \\
\text { knee extensions }\end{array}$ & $\begin{array}{l}15 \text { sets } \times 10 \mathrm{MVCs} \\
1 \text { min rest each set }\end{array}$ & $\begin{array}{c}\text { WP hydrolysate }+\mathrm{CHO} \\
(1: 1)(n=12)\end{array}$ & $\begin{array}{c}\text { Isocaloric } \mathrm{CHO} \\
(n=12) \\
\text { No dietary control }\end{array}$ & $\begin{array}{l}56 \mathrm{~g} 0 \mathrm{~h}, 24 \mathrm{~h}, 48 \mathrm{~h} \\
\text { post-exercise }\end{array}$ & $\begin{array}{l}\text { Peak isometric knee } \\
\text { extensor strength }\end{array}$ \\
\hline $\begin{array}{l}\text { Hamarsland et } \\
\text { al., 2017 [12] }\end{array}$ & $\begin{array}{l}\text { Trained men } \\
\text { and women }\end{array}$ & $\begin{array}{l}\text { Parallel } \\
\text { Groups }\end{array}$ & + & $\begin{array}{c}\text { Bilateral knee } \\
\text { extensions leg } \\
\text { presses }\end{array}$ & $\begin{array}{c}4 \text { sets } \times 8 \text { reps } \\
100 \% 8 \text { RM } \\
3 \text { min each set }\end{array}$ & $\begin{array}{l}\text { WP concentrate }(n=10) \\
\text { Native WP }(n=10)\end{array}$ & $\begin{array}{l}\text { Milk }(n=12) \\
\text { Fixed dietary } \\
\quad \text { control }\end{array}$ & $\begin{array}{l}20 \mathrm{~g} 0 \mathrm{~h} \text { and } 2 \mathrm{~h} \\
\text { post-exercise }\end{array}$ & $\begin{array}{l}\text { Peak isometric knee } \\
\text { extensor strength }\end{array}$ \\
\hline $\begin{array}{c}\text { Kim et al., } 2017 \\
\text { [13] }\end{array}$ & $\begin{array}{l}\text { Untrained } \\
\text { men }\end{array}$ & $\begin{array}{l}\text { Parallel } \\
\text { Groups }\end{array}$ & + & $\begin{array}{l}\text { Bilateral, isokinetic } \\
\text { eccentric elbow } \\
\text { flexions }\end{array}$ & 2 sets $\times 25$ MVCs & $\begin{aligned} \text { WP }(n=24)(3 \text { groups } \\
\quad \times n=8)\end{aligned}$ & $\begin{array}{c}\text { No } \\
\text { placebo/control } \\
\text { No dietary control }\end{array}$ & $\begin{array}{c}1.5 \mathrm{~g} / \mathrm{kg} . \\
\text { Immediately before } \\
\text { or after or before \& } \\
\text { after exercise }\end{array}$ & $\begin{array}{l}\text { Peak isometric elbow } \\
\text { flexor strength }\end{array}$ \\
\hline $\begin{array}{l}\text { Rindom et al., } \\
2016 \text { [14] }\end{array}$ & Trained men & Crossover & + & $\begin{array}{l}\text { Whole body } 5 \\
\text { exercises }\end{array}$ & $\begin{array}{c}3-5 \text { sets } \times \leq 12 \\
\text { reps per exercise, } \\
100 \% 15 \text { RM } 1.5 \text { min } \\
\text { rest each set }\end{array}$ & $\mathrm{WP}(n=12)$ & $\begin{array}{c}\text { Collagen protein } \\
(n=12) \\
\text { Fixed dietary } \\
\text { control }\end{array}$ & $\begin{array}{c}25 \mathrm{~g} \text { immediately } \\
\text { before and after } \\
\text { exercise } 24 \& 48 \mathrm{~h} \\
\text { post-exercise }\end{array}$ & $\begin{array}{l}\text { Peak isometric knee } \\
\text { extensor and flexor } \\
\text { strength, CMJ, 30 s } \\
\text { Wingate test, } 3 \mathrm{RMs}\end{array}$ \\
\hline $\begin{array}{l}\text { White et al., } \\
2008 \text { [16] }\end{array}$ & $\begin{array}{l}\text { Untrained } \\
\text { men }\end{array}$ & $\begin{array}{l}\text { Parallel } \\
\text { Groups }\end{array}$ & + & $\begin{array}{c}\text { Unilateral, } \\
\text { isokinetic, eccentric } \\
\text { knee extensions }\end{array}$ & $\begin{array}{l}5 \text { sets } \times 10 \mathrm{MVCs} \\
1 \text { min rest each set }\end{array}$ & $\begin{array}{c}\text { WP }+ \text { CHO (1:3) } \\
(n=18) \underset{\text { (2) }}{(2 \text { groups } \times n=}\end{array}$ & $\begin{array}{c}\text { Flavoured water } \\
(n=9) . \\
\text { No dietary control }\end{array}$ & $\begin{array}{l}98 \mathrm{~g} \text { Immediately } \\
\text { before or after } \\
\text { exercise }\end{array}$ & $\begin{array}{l}\text { Peak isometric knee } \\
\text { extensor strength }\end{array}$ \\
\hline
\end{tabular}

$\mathrm{CHO}=$ carbohydrate $\mathrm{CMJ}=$ countermovement jump; $\mathrm{MVC}=$ maximal voluntary contraction; $\mathrm{QA}=$ quality assessment; $\mathrm{RM}=$ repetition maximum; $\mathrm{WP}=$ whey protein. 


\subsection{Data Extraction}

Data pertaining to subjects' characteristics (sex and training status), experimental design (crossover/parallel, blinding, randomisation), function measure (type, time-point, muscle group), level of muscle damage (circulating creatine kinase (CK) level), RT intervention (load, volume, duty cycle, muscle action, muscle group), and supplementation strategy (dietary control, supplement control, dose, timing, type) was noted and reported (Table 1). For analysis, mean, SD, and sample size (n) were extracted (available from all included studies) from the treatment and control groups for each variable. These data were reported as either the post-treatment measurement in standard units, or as a percentage change pre-treatment to post-treatment.

\section{Analysis}

\subsection{Study Quality}

Study quality was categorised using the Quality Criteria Checklist for Primary Research to avoid bias [22] (Table 1). Briefly, studies were assessed on: (1) the research question being stated; (2) subject selection being free from bias; (3) compatible treatment groups; (4) method for withdrawals described; (5) blinding; (6) intervention details reported; (7) outcome(s) reported and valid; (8) appropriate statistical analysis; (9) appropriate conclusions stated and limitations cited; and (10) funding/sponsorship was free from bias. Items 2, 3, 6, 7, plus one other item was required for a positive rating (+), a neutral rating (o) was assigned if any of these items were not met, and a negative rating $(-)$ was given if six or more items were not reported.

\subsection{Meta-Analysis}

For the review and meta-analysis, from the eight included studies multiple independent (parallel) treatment groups were conducted in four studies $[9,12,13,16]$, which were analysed as independent RCTs (13 in total). The individual temporal effects $(k)$ within each RCT were identified as being $>3 \mathrm{~h}$ post-treatment [4], and for inclusion it was a precondition that a reduction in muscle function was observed in the control treatment; where no dysfunction occurs, no treatment effect can be observed.

Peak isometric knee extensor strength was used as the criterion functional measure for the meta-analysis, as it was (1) measured within all included studies reducing heterogeneity between effects; (2) the largest $k$ value amongst all reported functional measures (see definition above); and (3) in the extant literature the knee extensor muscles are a widely assessed/examined muscle group, and the isometric MVC is a criterion measure of strength/function holding high internal and external validity.

For the meta-analysis Hedges $g$ effect size (ES) was calculated for each effect by a pooled SD for both parallel and crossover designs, using the reported $\Delta$ values from all RCTs (i.e., \% change pre-treatment to post-treatment) [23]. Heterogeneity was assessed for each time-point by Cochran's $\mathrm{Q}(Q)$ and $I^{2}\left(<24 \mathrm{~h}, k=8, Q=20.6 ; p=0.004 ; I^{2}=66 \% ; 24 \mathrm{~h}, k=13 Q=29.8 ; p=0.003, I^{2}=60 \%\right.$; $48 \mathrm{~h}, k=7 Q=8.0 ; p=0.241, I^{2}=24 \% ; 72 \mathrm{~h}, k=7 Q=20.2 ; p=0.003, I^{2}=70 \% ; 96 \mathrm{~h}, k=7 Q=14.0$; $p=0.030, I^{2}=57 \%$ ) [24]. As 'small/moderate' heterogeneity was observed between ESs, a random effects model was used to calculate the pooled ESs which are reported with (lower, upper) 95\% CI [23] (R Studio 1.1.383). For temporal analysis, effects were collapsed into 24 -h epochs $(<24,24,48,72$ and $96 \mathrm{~h}$ ). A meta-regression and subgroup analysis was used to determine temporal effects and the effect of the experimental approach (SPSS 24). ESs are interpreted as $0.2=$ 'small'; $0.5=$ 'medium'; $0.8=$ 'large' ES [25].

\section{Results}

\subsection{Study Quality and Content}

All studies were positively ranked being of reasonably high quality. Predefined eligibility criteria were reported, control groups with random group allocation were used throughout, and appropriate 
experimental design/control/analysis/reporting was completed for all studies. All but one study [13] used a placebo as a control, in either a blind or double-blind experiment. Funding source(s), and a declaration of conflict/competing author interests(s) was reported in all but one study [16]. In total, 152 subjects were used from the eight included studies, consisting of 13 RCTs, with 42 temporal ESs. One study tested young, healthy women in a mixed-sex sample [12] with the remaining seven studies ( $\sim 92 \%$ of subjects) testing young, healthy men.

\subsection{Muscle Function}

Four of the included studies reported overall beneficial effects for WP compared to the control treatment $[9,10,15,16]$. No overall effect for WP was reported in the remaining four studies [11-14]. Only one negative temporal-treatment effect was reported [9], with ESs ranging widely within and between studies (-1.1 to 4.8) (Figure 1). From the meta-analysis, small to moderate effects were observed over time at $<24 \mathrm{~h}(\mathrm{ES}=0.6[0.1,1.0], z=2.00, p=0.046) ; 24 \mathrm{~h}(\mathrm{ES}=0.4[0.1,0.8], z=1.83$, $p=0.067) ; 48 \mathrm{~h}(\mathrm{ES}=0.4[-0.1,0.9], z=1.35, p=0.176) ; 72 \mathrm{~h}(\mathrm{ES}=0.7[0.2,1.3], z=1.35, p=0.025)$ and $96 \mathrm{~h}(\mathrm{ES}=0.4[-0.1,0.9], z=1.36, p=0.174)$. No moderator effect was observed for time $(\beta=0.001$, $z=0.677, p=0.498)$.

\subsection{Supplementation Strategy}

For all studies, WP was administered in a single bolus, the median dose being $25 \mathrm{~g}$ (range $=20 \mathrm{~g}$ to $\sim 120 \mathrm{~g}$ ). Sixty-two percent of the RCTs administered the WP bolus post-exercise, $23 \%$ pre-exercise, and $15 \%$ of treatments ingested WP pre- and post-exercise. Repeated WP boluses were given throughout the temporal recovery period in all but two studies [13,16], half of these studies gave subjects multiple boluses per day, and half administered WP at $24 \mathrm{~h}$ intervals throughout the temporal recovery period. Outside of the supplement dosing strategy, dietary intake was controlled in three studies, providing adequate and standardised dietary protein intake for all subjects $[12,14,15]$. The subjects in four of the remaining studies were asked to maintain their normal dietary intake, which was reported in two of these studies. Dietary information was provided in all but one study [9], but no information pertaining to subjects' individual dietary intake was reported. In lieu of the WP treatment a placebo/control drink was provided in all bar one study. An isocaloric $\mathrm{CHO}$ drink was the most common placebo/control in 3 out of the 8 studies. Other proteins low in essential amino acids (collagen), water, and mixed-macronutrient drinks (milk) were also used for the placebo/control treatment.

\subsection{Resistance Training Intervention}

Seventy percent of the RT interventions used eccentrically biased muscle actions at forces greater than one maximum repetition $(1 \mathrm{RM})$ or peak isometric force $\left(\mathrm{P}_{\mathrm{o}}\right)$-selecting untrained subjects for this RT intervention. The remaining studies used trained subjects undertaking performance or traditional RT (i.e., isoinertial $<1 \mathrm{RM} / \mathrm{P}_{\mathrm{o}}$ ). Small to medium overall ES were noted for both experimental approaches (untrained ES $=0.5[0.3,0.7]$; trained ES $=0.4[-0.1,0.9]$ ). Five studies measured the activity of a soluble enzyme released from the muscle, creatine kinase (CK), which is an indirect marker of exercise-induced muscle damage (EIMD). CK was not assessed further than $24 \mathrm{~h}$ in any of the performance-based RT interventions [12,14,15]. Following the eccentrically biased RT, CK activity was elevated for up to $96 \mathrm{~h}$ in four studies $[10,11,13,16]$, and no increase was observed in the one remaining study (measured at $24 \mathrm{~h}$ only) [9]. Temporal changes in muscle soreness correlated with CK, remaining elevated above baseline up to $96 \mathrm{~h}$ in all five of the eccentrically biased RT studies. No temporal beneficial effect for WP was observed for CK activity or muscle soreness in any study. 


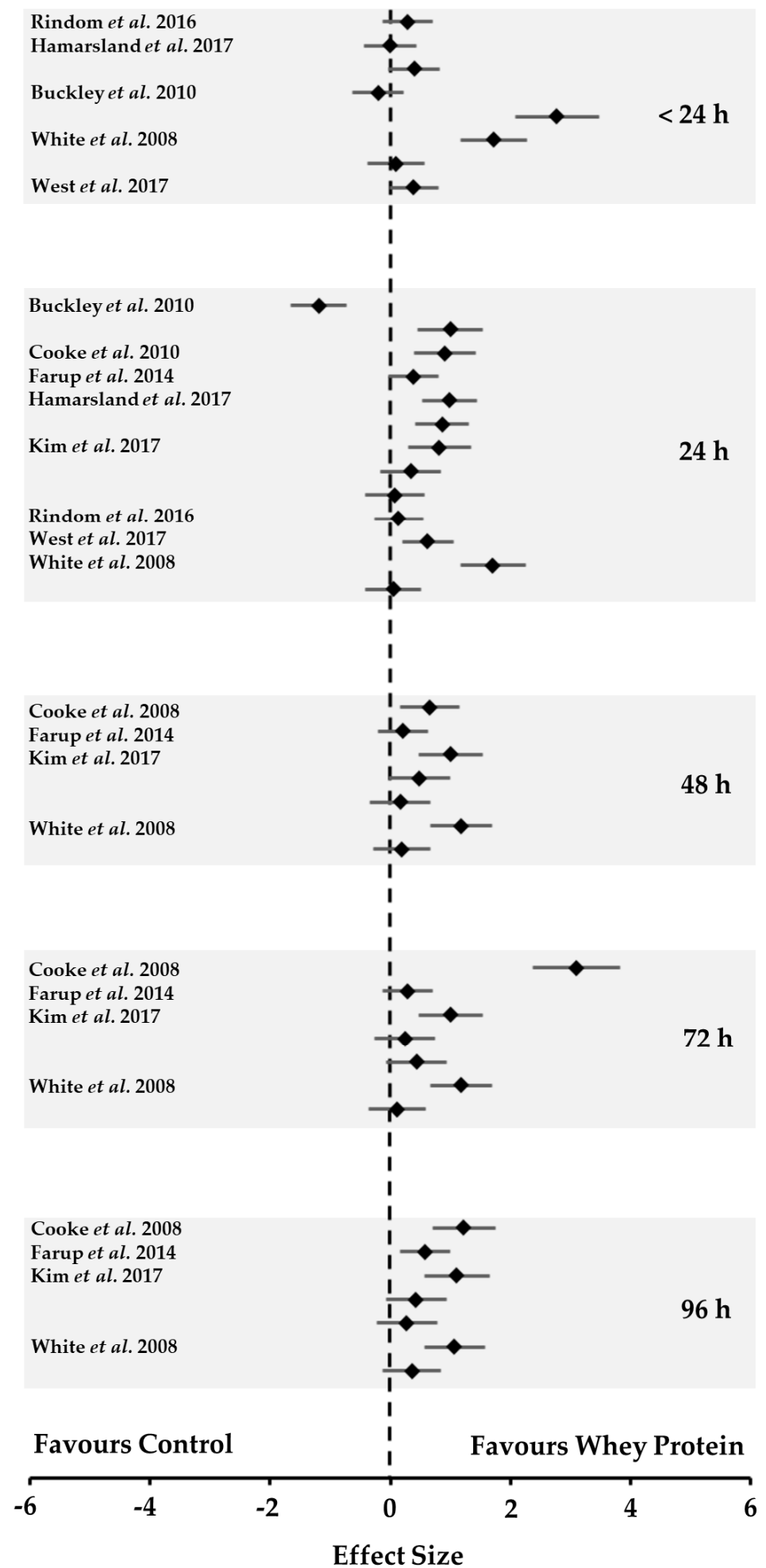

Figure 1. Forest plot of the temporal effect sizes (ESs) of the whey protein supplement for the recovery of muscle function following resistance training, compared to a control treatment. Data are mean $\pm 95 \%$ CI. ESs are ordered by time.

\section{Discussion}

Overall small to medium ergogenic effects were observed for WP supplementation restoring muscle contractile function following RT from $<24$ to $96 \mathrm{~h}$ (ES range $=0.4-0.7$ ). Half of the included 
studies reported a beneficial overall effect for WP, whilst the other half concluded no effect occurred compared to the control. No study reported any overall negative effect for WP and only one negative effect (favouring the control) was reported out of the 44 temporal comparisons. Although the RCTs were of reasonably high quality, significant heterogeneity was observed between studies.

\subsection{Experimental Approaches to the Problem}

A clear break point was identified between two experimental approaches. A dichotomy was observed for the selection of (1) subject population (i.e., trained or untrained); (2) muscle action (i.e., eccentric only or concentric + eccentric); and (3) load (<or $>1 \mathrm{RM} / \mathrm{P}_{\mathrm{o}}$ ). In five studies it is clear that one experimental approach was used to evoke overt EIMD, dysfunction and/or soreness [9-11,13,16], however, a 'performance-based' approach was employed in the remaining three more recent studies $[12,14,15]$. Whilst there are fundamental differences between these two approaches, similar effects were observed for WP. On review, no consensus on the efficacy of WP was attained in either subgroup.

Similar, contrasting results have been observed in the wider extant literature, following alternative forms of damaging exercise [26-28], and/or high-protein mixed macronutrient [29-35], performance-based exercise interventions [29,36], or within a more general systematic review [37]. There was no definitive evidence to suggest that WP reduced markers of EIMD or muscle soreness following RT. Whilst this is the first review quantifying overall temporal ES, the constituent studies are biased towards purposefully damaging exercise. Other than more recent investigations [12,14,15], generally, performance-based exercise interventions are rarely used limiting the ecological and external validity of these findings.

Outside of the criterion functional measure of peak isometric torque, two studies conducted additional performance-based testing in line with the RT intervention (i.e., countermovement jump, RT performance, and anaerobic performance) $[14,15]$. Although similarities were noted between studies for the sample-population, supplement strategy, outcome measures and RT intervention, contrasting results were reported, requiring further conclusive research.

\subsection{Supplementation Strategy}

WP is a widely researched and well characterised supplement with known bioactivity and biokinetics. The amount of WP required to optimise post-exercise anabolism approximates to 20 $\mathrm{g}$ [4,7], which was achieved in all 13 RCTs. The timing of the protein feed varied, and whilst pre-exercise ingestion is shown to enhance post-exercise recovery (c.f. post-exercise ingestion [16]), these findings were not consistent, with the timing of WP ingestion also not shown to effect post-exercise recovery [13]. Repeated WP doses were administered throughout the temporal recovery period in all but two studies, either as repeated daily doses or at $24 \mathrm{~h}$ intervals. The amount of protein ingested from the WP supplement constituted only a fraction of the total dietary protein intake during the period of recovery. As dietary control was absent in $70 \%$ of the RCTs, the influence of dietary protein source, quantity and distribution between subjects and treatment groups is a further confounder to the outcome, and potentially the greatest source of variation between the observed effects, which is highlighted as a major limitation in the extant literature.

In addition to the considerations above, a variety of placebos/controls were utilised in the RCTs. Whilst effects have been observed for WP compared to neutral (non-anabolic) controls (i.e., $\mathrm{CHO}$ and water [4]) null effects were generally reported for studies using lower-quality protein supplements or milk as a control [30,32,33]. It is possible that potential bioactivity of any placebo/control could ameliorate the treatment effect of the WP, a potential confounder to the outcome.

\subsection{Other Considerations}

Considering the high prevalence of WP consumption amongst people undertaking regular RT [38], it was surprising that only eight high-quality studies have been published over a period 
of 10 years. The authors noted a similar number of eligible studies were reported within the grey literature, which for quality control were not included in this review and meta-analysis. An obvious sex bias was also observed, with the authors identifying the need for further high-quality research-specifically directed toward the performance-based experimental approach (viz. trained subjects, performance-based RT / functional measures, repeated bouts). Additionally, whilst empirically advanced by some $[11,14,15,39]$, in the absence of integrative or confirmative evidence supporting a physiological mechanism(s) that adequately explains the acute loss of muscle function following RT, the promotion of a protein-supplement based strategy to enhance the recovery of function is limited.

\section{Conclusions}

This systematic review identified eight individual studies consisting of 13 RCTs that satisfied the criteria for inclusion in the meta-analysis. A small to medium temporal ergogenic effect was observed for WP, accelerating the recovery of muscle function following RT, with under half of the RCTs reporting beneficial overall effects for WP. The findings from this systematic review and meta-analysis are limited to eight studies, and considered underpowered for further analysis/control of other extraneous and/or potentially confounding factors such as the subject characteristics, mode/purpose of exercise, and/or the supplementation strategy. Authors caution against interpreting the overall temporal ES reported in this study as definitive evidence. Rather, it is suggested these findings are understood as a synthesis of the literature to date, reflecting the dispersion, limitations, and overall effects between the RCTs in the extant literature, identifying the need for further experimental research in this area.

Acknowledgments: This study was supported by Food Health Ireland (FHI) TC20130001.

Author Contributions: R.W.D., B.P.C. and P.M.J. designed and conceived the systematic review. R.W.D. conducted the literature search, study selection, and analysis. R.W.D., B.P.C., and P.M.J. wrote and approved final revisions of the manuscript submitted for publication.

Conflicts of Interest: The authors declare no conflict of interest. The sponsors had no role in the design, collection, analysis, interpretation of the data, writing of the manuscript, or in the decision to publish the results.

\section{References}

1. Jones, D.A.; Rutherford, O.M.; Parker, D.F. Physiological changes in skeletal muscle as a result of strength training. Q. J. Exp. Physiol. 1989, 74, 233-256. [CrossRef] [PubMed]

2. Byrne, C.; Byrne, R. The effect of exercise-induced muscle damage on isometric and dynamic knee extensor strength and vertical jump performance. J. Sports Sci. 2002, 20, 417-425. [CrossRef] [PubMed]

3. Warren, G.L.; Lowe, D.A.; Armstrong, R.B. Measurement tools used in the study of eccentric contraction-induced injury. Sports Med. 1999, 27, 43-59. [CrossRef] [PubMed]

4. Atherton, P.J.; Smith, K. Muscle protein synthesis in response to nutrition and exercise. J. Physiol. 2012, 590, 1049-1057. [CrossRef] [PubMed]

5. West, D.W.; Burd, N.A.; Coffey, V.G.; Baker, S.K.; Burke, L.M.; Hawley, J.A.; Moore, D.R.; Stellingwerff, T.; Phillips, S.M. Rapid aminoacidemia enhances myofibrillar protein synthesis and anabolic intramuscular signaling responses after resistance exercise. Am. J. Clin. Nutr. 2011, 94, 795-803. [CrossRef] [PubMed]

6. Morton, R.W.; Murphy, K.T.; McKellar, S.R.; Schoenfeld, B.J.; Henselmans, M.; Helms, E.; Aragon, A.A.; Devries, M.C.; Banfield, L.; Krieger, J.W.; et al. A systematic review, meta-analysis and meta-regression of the effect of protein supplementation on resistance training-induced gains in muscle mass and strength in healthy adults. Br. J. Sports Med. 2017. [CrossRef] [PubMed]

7. Witard, O.C.; Jackman, S.R.; Breen, L.; Smith, K.; Selby, A.; Tipton, K.D. Myofibrillar muscle protein synthesis rates subsequent to a meal in response to increasing doses of whey protein at rest and after resistance exercise. Am. J. Clin. Nutr. 2014, 99, 86-95. [CrossRef] [PubMed]

8. Tang, J.E.; Moore, D.R.; Kujbida, G.W.; Tarnopolsky, M.A.; Phillips, S.M. Ingestion of whey hydrolysate, casein, or soy protein isolate: Effects on mixed muscle protein synthesis at rest and following resistance exercise in young men. J. Appl. Physiol. 2009, 107, 987-992. [CrossRef] [PubMed] 
9. Buckley, J.D.; Thompson, R.L.; Coates, A.M.; Howe, P.R.; DeNichilo, M.O.; Rowney, M.K. Supplementation with a whey protein hydrolysate enhances recovery of muscle force-generating capacity following eccentric exercise. J. Sci. Med. Sport. 2010, 13, 178-181. [CrossRef] [PubMed]

10. Cooke, M.B.; Rybalka, E.; Stathis, C.G.; Cribb, P.J.; Hayes, A. Whey protein isolate attenuates strength decline after eccentrically-induced muscle damage in healthy individuals. J. Int. Soc. Sports Nutr. 2010, 7, 30. [CrossRef] [PubMed]

11. Farup, J.; Rahbek, S.K.; Knudsen, I.S.; de Paoli, F.; Mackey, A.L.; Vissing, K. Whey protein supplementation accelerates satellite cell proliferation during recovery from eccentric exercise. Amino Acids 2014, 46, 2503-2516. [CrossRef] [PubMed]

12. Hamarsland, H.; Nordengen, A.L.; Aas, S.N.; Holte, K.; Garthe, I.; Paulsen, G.; Cotter, M.; Børsheim, E.; Benestad, H.B.; Raastad, T. Native whey protein with high levels of leucine results in similar post-exercise muscular anabolic responses as a regular whey protein: A randomized control trial. J. Int. Soc. Sports Nutr. 2017, 14. [CrossRef] [PubMed]

13. Kim, J.; Chulhyn, L.; Joohyung, L. Effect of timing of whey protein supplement on muscle damage markers after eccentric exercise. J. Exerc. Rehabil. 2017, 13, 436-440. [CrossRef] [PubMed]

14. Rindom, E.; Nielsen, M.H.; Kececi, K.; Jensen, M.E.; Vissing, K.; Farup, J. Effect of protein quality on recovery after intense resistance training. Eur. J. Appl. Physiol. 2016, 116, 2225-2236. [CrossRef] [PubMed]

15. West, D.W.; Abou Sawan, S.; Mazzulla, M.; Williamson, E.; Moore, D.R. Whey protein supplementation enhances whole body protein turnover and performance recovery after resistance exercise: A double-blind crossover study. Nutrients 2017, 9. [CrossRef] [PubMed]

16. White, J.P.; Wilson, J.M.; Austin, K.G.; Greer, B.K.; St John, N.; Panton, L.B. Effect of carbohydrate-protein supplement timing on acute exercise-induced muscle damage. J. Int. Soc. Sports Nutr. 2008, 5. [CrossRef] [PubMed]

17. Moher, D.; Liberati, A.; Tetzlaff, J.; Altman, D.G. Preferred reporting Items for Systematic Review and Meta-analysis: The PRISMA Statement. Ann. Intern. Med. 2009, 151, 264-269. [CrossRef] [PubMed]

18. Warren, G.L.; Park, N.D.; Maresca, R.D.; McKilbans, K.I.; Millard-Stafford, M.L. Effect of caffeine ingestion on muscular strength and endurance: A meta-analysis. Med Sci Sports Exerc. 2010, 42, 1375-1387. [CrossRef] [PubMed]

19. Rowlands, D.S.; Thomson, J.S. Effects of beta-hydroxy-beta-methylbutyrate supplementation during resistance training on strength, body composition, and muscle damage in trained and untrained young men: A meta-analysis. J. Strength Cond. Res. 2009, 23, 836-846. [CrossRef] [PubMed]

20. Foure, A.; Bendahan, D. Is Branched-Chain Amino Acid supplementation an Efficient Nutritional Strategy to Alleviate Skeletal Muscle Damage? A Systemic Review. Nutrients 2017, 9. [CrossRef]

21. Morelli, K.M.; Brown, L.B.; Warren, G.L. Effect of NSAIDs on Recovery from Acute Skeletal Muscle Injury: A Systematic Review and Meta-analysis. Am J Sports Med. 2018, 46. [CrossRef] [PubMed]

22. AND. Evidence Analysis Manual: Steps in the Academic Evidence Analysis Process. Available online: https:/ / www.andeal.org/vault/2440/web/files/QCC_3.pdf (accessed on 15 December 2017).

23. Borenstein, M.; Hedges, L.V.; Higgins, J.P.T.; Rothstein, H.R. Introduction to Meta-Analysis; Wiley: Hoboken, NJ, USA, 2009; ISBN 978-0-470-05724-7.

24. Higgins, J.P.T.; Thompson, S.G.; Deeks, J.J.; Altman, D.G. Measuring inconsistency in meta-analyses. BMJ 2003, 327, 557-560. [CrossRef] [PubMed]

25. Cohen, J. A power primer. Psychol. Bull. 1992, 112, 155-159. [CrossRef] [PubMed]

26. Blacker, S.D.; Williams, N.C.; Fallowfield, J.L.; Bilzon, J.L.J.; Willems, M.E.T. Carbohydrate vs. protein supplementation for recovery of neuromuscular function following prolonged load carriage. J. Int. Soc. Sports Nutr. 2010, 7, 2. [CrossRef] [PubMed]

27. Brown, M.A.; Stevenson, E.J.; Howatson, G. Whey protein hydrolysate supplementation accelerates recovery from exercise-induced muscle damage in females. Appl. Physiol. Nutr. Metab. 2017. [CrossRef] [PubMed]

28. Eddens, L.; Browne, S.; Stevenson, E.J.; Sanderson, B.; van Someren, K.; Howatson, G. The efficacy of protein supplementation during recovery from muscle-damaging concurrent exercise. Appl. Physiol. Nutr. Metab. 2017, 42, 716-724. [CrossRef] [PubMed]

29. Betts, J.A.; Toone, K.A.; Thompson, D. Systematic indices of skeletal muscle damage and recovery of muscle function after exercise: Effect of combined carbohydrate-protein ingestion. Appl. Physiol. Nutr. Metab. 2009, 34, 773-784. [CrossRef] [PubMed] 
30. Cockburn, E.; Bell, P.G.; Stevenson, E. Effect of milk on team sport performance after exercise-induced muscle damage. Med. Sci. Sports Exerc. 2013, 45, 1585-1592. [CrossRef] [PubMed]

31. Cockburn, E.; Hayes, P.R.; French, D.N.; Stevenson, E.; St Clair Gibson, A. Acute milk-based protein-cho supplementation attenuates exercise-induced muscle damage. Appl. Physiol. Nutr. Metab. 2008, 33, 775-783. [CrossRef] [PubMed]

32. Cockburn, E.; Robson-Ansley, P.; Hayes, P.R.; Stevenson, E. Effect of volume of milk consumed on the attenuation of exercise-induced muscle damage. Eur. J. Appl. Physiol. 2012, 112, 3187-3194. [CrossRef] [PubMed]

33. Cockburn, E.; Stevenson, E.; Hayes, P.R.; Robson-Ansley, P.; Howatson, G. Effect of milk-based carbohydrate-protein supplement timing on the attenuation of exercise-induced muscle damage. Appl. Physiol. Nutr. Metab. 2010, 35, 270-277. [CrossRef] [PubMed]

34. Etheridge, T.; Philp, A.; Watt, P.W. A single protein meal increases recovery of muscle function following an acute eccentric exercise bout. Appl. Physiol. Nutr. Metab. 2008, 33, 483-488. [CrossRef] [PubMed]

35. Rankin, P.; Stevenson, E.; Cockburn, E. The effect of milk on the attenuation of exercise-induced muscle damage in males and females. Eur. J. Appl. Physiol. 2015. [CrossRef] [PubMed]

36. Rankin, P.; Lawlor, M.J.; Hills, F.A.; Bell, P.G.; Stevenson, E.J.; Cockburn, E. The effect of milk on recovery from repeat-sprint cycling in female team-sport athletes. Appl. Physiol. Nutr. Metab. 2018, 43, 113-120. [CrossRef] [PubMed]

37. Pasiakos, S.M.; Lieberman, H.R.; McLellan, T.M. Effects of protein supplements on muscle damage, soreness and recovery of muscle function and physical performance: A systematic review. Sports Med. 2014, 44, 655-670. [CrossRef] [PubMed]

38. Goston, J.L.; Correia, M.I. Intake of nutritional supplements among people exercise in gyms and influence factors. Nutrition 2010, 26, 604-611. [CrossRef] [PubMed]

39. Rahbek, S.K.; Farup, J.; Møller, A.B.; Vendelbo, M.H.; Holm, L.; Jessen, N.; Vissing, K. Effects of divergent resistance exercise contraction mode and dietary supplementation type of anabolic signalling, muscle protein synthesis and muscle hypertrophy. Amino Acids 2014, 46, 2377-2392. [CrossRef] [PubMed]

(C) 2018 by the authors. Licensee MDPI, Basel, Switzerland. This article is an open access article distributed under the terms and conditions of the Creative Commons Attribution (CC BY) license (http:/ / creativecommons.org/licenses/by/4.0/). 